PEDAGÓGUSKÉPZÉS, 10-11 (39-40), 2012-2013. 189-194.

\title{
INNOVATÍV RENDSZERSZEMLÉLET A PEDAGÓGIÁBAN
}

\author{
BALOGH ADRIENN \\ az Eszterházy Károly Főiskola Neveléstudományi Doktori Iskolájának \\ hallgatója \\ balogh.adrienn2@gmail.com
}

Az alkotás nemcsak kreatív elmét, szakértő kezet, hanem végtelen türelmet kíván. A folyamat végén mindannyian a szó bizonyos értelmében remekmüvet várunk, legyen az alkotó müvész, építész vagy esetünkben a rendszerszemlélettel gondolkodó pedagógus. Egyre több segédeszköz áll rendelkezésünkre, melyek megkönnyítik, hatékonnyá teszik munkánkat az élet minden területén. Az eszközök hatékony használata megkívánja az alkotó és/vagy felhasználó folyamatos képzését, támogatását. A hangsúly a folyamaton van, melynek során lépésröl-lépésre (lépéseket ki nem hagyva) vezetik a felhasználót a rendszer megalkotásáig. A fokozatosság rendkívül fontos, hiszen egyetlen lépés kihagyása is összeomlással fenyeget akár müvészi, akár pedagógiai kompozícióban (jelen esetben rendszerben) gondolkodunk.

A tanár, mint a tudás kizárólagos forrása - szerep folyamatosan megkérdőjeleződik a 21. században. Jelentős változást hoztak a 20. században megjelent oktatástechnikai és informatikai eszközök, majd később a rendszerszemlélet térhódítása, az oktatócsomagok, a curriculum jellegü tanterv és a programcsomagok megjelenése. A legújabb kihívást a digitalizáció térhódítása mellett egy olyan, a differenciálást és adaptivitást lehetővé tevő eszközrendszer létrehozása és alkalmazása jelenti a szakemberek és pedagógusok számára, amely a tanulók szükségleteinek függvényében eltérő tanulási-tanítási egységeket tartalmaz és minden egységen belül alternatív, a tanulók képességeihez, érdeklődéséhez, tempójához igazítható tanítási eszközöket, munkaformákat bocsát rendelkezésre.

Ez a többszerzős tanulmánykötet arra vállalkozik, hogy ebben a kézikönyvben az olvasók egy, a korszerủ szemléletet is megvalósító pedagógiai rendszer tervezéséhez, készítéséhez és alkalmazásához kapjanak megfelelő muníciót. A pedagógiai rendszerek fejlesztése, bevezetése és alkalmazása szakember- és egyben költségigényes, mégis számos érv szól alkalmazásuk mellett. A teljesség igénye nélkül ezek közül csak néhányat említek. A kötetben ismertetett hételemű rendszer (pedagógiai koncepció, tanulási-tanítási program, tanulási-tanítási egységleírások, tanulási-tanítási eszközök, értékelés és eszközei, pedagógusok felkészítési programjai, szakmai háttértámogatás és programkarbantartás) átfogja az oktató-nevelő tevékenység teljességét, a pedagógiai koncepció felkínálásától a rendszer beválásának ellenőrzéséig. A rendszerszerüségnek köszönhetően az egyes elemek szervesen kapcso- 
lódnak, egymás hatását erősítik, egymást kiegészítik. A pedagógiai rendszert, mint „egészet” kell akkreditáltatni, így ellenőrizhető az elemek kapcsolódása, a szinergiák, a koherencia, továbbá az egységesség és a minőség garantált. A pedagógiai rendszert, mint egy elvárhatóan jól müködő órát kell elképzelni, ahol minden fogaskerék (elem) müködése (vagy müködésképtelensége) hatással van a többi komponensre és így végeredményben az egész pedagógiai rendszer hatékonyságára.

A kézikönyv nyolc fejezetben tárgyalja a pedagógiai rendszerek történeti fejlődésének alakulását, a fogalom lényeges ismérveit, a fejlesztés, a bevezetés, az akkreditáció, a finanszírozás, a beválás lényeges kérdéseit. A célközönség széles: a pedagógiai rendszerek megrendelői, fejlesztői, az iskolafenntartók, innovatív pedagógusok, az akkreditáció, a finanszírozás, a támogatás és az értékelés folyamatában közremüködő szakemberek mind haszonnal forgathatják ezt a kiadványt.

Az első fejezetben európai példákon (Hollandia, Nagy Britannia tagországai) és az Amerikai Egyesült Államok - Kalifornia, valamint Magyarország tapasztalatainak feldolgozása alapján megismerhetjük a pedagógiai rendszerek elődjeit, föként azokat, melyek tanulságul szolgálhatnak a pedagógiai rendszerek fejlesztői számára. A fejezet három alfejezetre tagolódik: a külföldi tapasztalatok után a hazai oktatáspolitikai és szakmai dokumentumokat vizsgálja a kötet a fogalom használata szempontjából, majd a harmadik rész az elmúlt évtizedek négy jelentős magyar innovációjának (reformpedagógiai iskolák; alternatív iskolák; „részben alternatív” iskolák, melyek struktúrájukban és pedagógiai programjaikban, néhol oktatásrólnevelésről vallott filozófiájukban eltérnek az általánostól; kompetenciafejlesztési csomagok) elemzési eredményeiről számol be.

A bemutatott három ország gyakorlata sok hasonlóságot mutat, föleg a pedagógiailag meghatározott tartalmi kérdéseket illetően. Eltérések a fejlesztés szereplői, a fejlesztés kiterjedése és a folyamat ellenőrzése, értékelése között van, illetve abban, hogy a fejlesztésekben milyen súllyal van jelen a gazdasági, üzleti szempont. A hazai szakirodalmat és oktatáspolitikai dokumentumokat illetően a komplex rendszerben való gondolkodás, a korszerü pedagógiai elveken alapuló alternatívákat biztosító fejlesztések melletti elkötelezettség és a taneszköz rendszerek jelentőségének elismerése jellemző. Meghatározó különbség a pedagógiai rendszerek kiterjedtségének értelmezésében van, mely értelmezések jelenleg is egymás mellett élnek.

Az innovatív pedagógiai rendszerek ismertetésekor a kötet ide vonatkozó tanulmányának szerzői kitérnek a Waldorf-pedagógia, Értékközvetítő és képességfejlesztő pedagógiai koncepció, Alternatív Közgazdasági Gimnázium, Kompetenciaalapú programcsomagok, mint pedagógiai rendszerek struktúrájának, tartalmi elemeinek, a programok kipróbálásának, beválás-vizsgálatának és az elterjesztés feltételeinek részletes bemutatására. A kötet szerzői arra a megállapításra jutnak, hogy a rendszer kidolgozottságától függően kell a felhasználók támogatását biztosítani a megvalósítás stratégiájának szabadsága mellett. 
A második fejezetben szereplő tanulmányban megtudhatjuk, hogy a szerzők a pedagógiai rendszer olyan meghatározására törekszenek, amely alkalmas minden rendszerfejlesztés befogadására, nem zárja ki a nem országosan irányított, hanem a helyi kezdeményezésre megvalósuló fejlesztéseket sem. A hazai és nemzetközi tapasztalatokra alapozva a pedagógiai rendszereknek négy fö fajtáját jeleníti meg a kötet. 1. Teljes tantárgy, vagy annak valamely részegysége; 2 . Egy müveltségi terület, azaz több, egymással összehangolt és összetartozó tantárgy, illetve kulcskompetencia; 3. Egy adott iskola pedagógiai programja, helyi tanterve; 4. Egy oktatási, intézményi rendszer egészére vagy részére (pedagógiai szakasz) irányuló fejlesztés, beleértve a közoktatás egy horizontálisan teljes és vertikálisan egységes szakaszára kiterjedő rendszereket is.

A tanulmány definiálja a korábbiakban már említett hételemü rendszer elemeit, azok alkalmazási módjait, elvezetve az olvasót a nevelési-oktatási célok, tartalom, módszerek, eszközök felsorolásához, bemutatásához. A szerzők az első fejezetben bemutatott nemzetközi vizsgálódás eredményei alapján igazoltnak látják, hogy a pedagógiai rendszer ,hungarikum”, melynek létezését a magyar valóság sem igazolja. A vizsgált modellek nagy része csak részben felel meg a pedagógiai rendszer a szerzők által értelmezett fogalmi rendszerének, melynek elemei együtt egy modellben sem jelennek meg, ezért megkérdőjeleződik az elnevezés célszerüsége. Megmarad a létjogosultsága az oktatási program és a programcsomag szó használatának, melyek egyben a pedagógiai rendszereknek is a meghatározó jelentőségü magját jelentik. A pedagógiai rendszer elnevezés jelen esetben azon megfontoláson alapul és jelent többet a már említett programcsomagok a szerzők által szükebbnek vélt tartalmánál, hogy itt a pedagógusok felkészítése és rendszeres támogatása is helyt kap.

A harmadik fejezet, szervesen a második fejezetre épülve, a pedagógiai rendszerek fejlesztésének feltételeit és lépéseit ismerteti. Az eszközök komplexitása miatt a fejlesztés rendkívül bonyolult és szerteágazó feladat. Függetlenül attól, hogy milyen léptékủ rendszer kidolgozására kerül sor a fejlesztés alapvető fázisainak (I. előkészítő szakasz, II. fejlesztő szakasz és a kipróbálás, III. az implementáció előkészítése) megvalósítása elengedhetetlen. A fejlesztési munkafolyamat minden esetben a pedagógiai rendszerek esetében definiált és egymásra épülő hét elem kimunkálását célozza. Az áttekintést és a megértést könnyíti A fejlesztési munkafolyamat részletes leírása c. alfejezetben található több oldalas táblázat, amelyben a tanulmány szerzői részletesen bemutatják a fejlesztési munkafolyamatot, az egyes szakaszokban szükséges szakmai-fejlesztési és menedzsmenttevékenységeket, az azok eredményeként létrejövő produktumokat, a minőségbiztosítási feltételeket, beleértve annak tartalmi, formai és humánerőforrás szükségleteit is. A táblázat alapján elkészített pedagógiai rendszer tulajdonképpen alkalmas lehet arra, hogy készítői akkreditációnak vessék alá, illetve a tanítási gyakorlatban bevezessék.

A kötet negyedik fejezetében szereplő tanulmány szerzői a pedagógiai rendszerek akkreditációs lehetőségeivel ismertetik meg az olvasót és leendő alkotó-felhasználót. 
A szerzőkkel egyetérthetünk abban, hogy egy pedagógiai rendszer - amelyben az egyes elemek kölcsönhatásban vannak, szerves egységet alkotnak - a rendszer egészének egységes akkreditációját igényli. Mivel a jelenlegi akkreditációs eljárások alkalmatlanok a pedagógiai rendszer egységben történő vizsgálására, ezért a szerzők úgynevezett ellenőrző listás (csekklistás) egylépcsős és kétlépcsős akkreditációs eljárás bevezetésére tesznek javaslatot. A szerzők mindkét általuk javasolt akkreditációs eljárás előnyeit és hátrányait is ismertetik az olvasóval. Nem esnek abba a hibába, hogy a bármi áron történő megvalósítás felé orientálják a felhasználót, inkább lehetséges alternatívákat kínálnak megmutatva azok lehetséges alkalmazási területeit rábízva a döntést a jövőbeni alkalmazókra. Feltárják az akkreditációs eljárások jogszabályi környezetét, illetve bemutatják a rendszer-akkreditációs eljárás szakértő résztvevőit is. A fejezet végén található folyamatábra szemlélteti az akkreditációs eljárás megvalósulását.

Az ötödik fejezet a pedagógiai rendszerek bevezetésének (implementációjának) kérdéseit tárgyalja. A kötet a rendszerek bevezetésének négy fajtáját különbözteti meg: 1. oktatáspolitikai döntésből következő implementáció (pl. NAT); 2. központi szervezet és/vagy pályázat által támogatott implementáció (pl. suliNova fejlesztések, HEFOP-, TÁMOP-pályázatok); 3. belső iskolafejlesztések eredményeiből adódó implementáció (pl. AKG); 4. az oktatási piacon szabadon fellelhető pedagógiai rendszerek implementációja (pl. taneszköz gyártók, kiadók, helyi kezdeményezések). A szerzők által javasolt implementációs lépéssor a 2. és 4. változatnál alkalmazható, amikor az oktatási intézménynek lehetősége van a pedagógiai rendszerek kínálatából választani és dönteni. Az implementációs szakasz három részre bontható: a felkészülés, a kipróbálás és a fenntartás szakaszára. A szerzők kiemelten fontos feladatnak tartják a pedagógusok felkészítését az új program alkalmazására (továbbképzések). Attól függően, hogy a pedagógiai rendszer mely típusú implementáció alapján valósul meg, beszélhetünk alkotó, adaptáló vagy végrehajtó pedagógusszerepekről. A tanulmány szerzői az implementáció folyamatának részletes leírásával azt mutatják be, hogy ideális helyzetben melyek azok a teendők, amelyek elvégzésével a bevezetés várhatóan sikeres lesz. Az implementáció bemutatását egy folyamatábra is segíti, amely tagolja a pedagógiai rendszerek gyakorlatba történő bevezetésének folyamatát, melynek kulcsfogalmai a tervszerüség és a tudatosság. Az implementáció folyamatában fontos és a sikeresség előfeltétele az adott iskola pedagógusainak tájékoztatása akkor is, ha az implementáció nem érinti az egész intézményt. Egyébként a kommunikáció fontosságára a kötet utolsó, a beválás vizsgálattal foglalkozó tanulmánya is felhívja a figyelmet. A fejezethez tartozó mellékletben a megértést segítő folyamatábrán kívül (a teljesség igénye nélkül felsorolva) összefoglaló táblázatok is találhatók például a különböző szakaszokban részt vevők felelösség- és hatásköreiröl; az implementációs folyamatban alkalmazott dokumentumokról, a felsoroltakon kívül szerepel még döntési mátrix, feladatlista, ütemterv és munkanapló sablon, eseménylap a tapasztalatok folyamatos rögzítéséhez, SWOT-analízislap - egy valódi dokumentum-eszköztár az olvasók, későbbi felhasználók részére. 
A hatodik fejezet a pedagógiai rendszerek fejlesztésének és alkalmazásának finanszírozási kérdéseit tárgyalja. Megkülönbözteti a finanszírozás és a finanszírozhatóság fogalmát, melyek szétválasztását azonban nem tartja kívánatosnak. A szerzők együtt tárgyalják a finanszírozás és a fenntarthatóság folyamatát. A fejezetben szereplö tanulmány szerzőinek álláspontja szerint olyan finanszírozási modellekre van szükség, amelyek egyszerre többféle cél megvalósulását is szolgálni tudják. Az alapvető célok közé tartozik a magas színvonalú fejlesztő munkához szükséges szakmai környezet biztosítása; a pedagógiai rendszerek iskolai elterjedésének gyorsítása; az esélyegyenlőség biztosítása a kis létszámú diákcsoportoknak; az állami támogatások hatékony felhasználása; az állami támogatás és a kiadók kockázatvállalása közötti egyensúly megvalósítása a pedagógiai rendszerek kifejlesztésének és forgalmazásának hosszú távú fenntarthatósága érdekében. Az előbbiekben ismertetett célok elérése érdekében a fejezet két pályázati és egy üzleti modellt kínál az olvasónak. A modellek az eltérő pedagógiai rendszerek fejlesztései esetében másmás hatékonysággal alkalmazhatók. Az olvasó (későbbi felhasználó) választását itt is segítik a szerzők az egyes modellek előnyeinek és hátrányainak ismertetésével. A szerzők felhívják a figyelmet arra is, hogy bizonyos folyamatok végkimenetelének bejósolhatatlansága miatt a felvázolt finanszírozási modellek helyenként ellentmondanak egymásnak. A fejezet ismerteti a pedagógiai rendszerek közös kereteit jelentő új jogi környezetet (a Nemzeti alaptanterv, a kerettanterv, a helyi pedagógiai program vonatkozásában), illetve bemutatja, hogyan befolyásolja a pedagógiai rendszerek finanszírozhatóságát és fenntarthatóságát az új jogszabályi környezet. A szerzők által javasolt modellek bemutatásán túl a tanulmány szerzői ismertetik a közölt teoretikus modellek mozgásterét csökkentő tényezőket is (például a NAT által támasztott pontosabb tartalmi megkötések, a kerettantervek is tovább szükítik a mozgásteret, a tankönyvterjesztés centralizációja stb.). A fejezet végén az olvasó megismerheti az új körülményekhez igazított változatokat.

A hetedik fejezet a pedagógiai rendszer fejlesztését támogató informatikai felületet mutatja be. Ennek során az ide vonatkozó tanulmány szerzői előbb megfogalmazzák az informatikai fejlesztőfelület létrehozásának szakmai-módszertani, valamint projektirányítási indokoltságát, majd részletesen ismertetik müködését, használatának módját. Az informatikai felület segítségével fejlesztett pedagógiai rendszer leképezi a pedagógiai rendszer előző fejezetekben megfogalmazott meghatározásait, müködési eljárásai figyelembe veszik a pedagógiai rendszerek javasolt fejlesztési eljárásait és a pedagógiai rendszerekhez hasonló komplex tartalomhordozók korábbi fejlesztéseinek tapasztalatait. A 21. századi digitalizációs kihívásokra visszautalva a szerzők álláspontja szerint is természetes igénynek tekinthető, hogy a pedagógiai rendszerek fejlesztését olyan informatikai eszközrendszer segítse, amely alkalmas a fejlesztés során felmerülő összes feladat támogatására és a felmerülő problémák kezelésére. A fejezetben több magyarázó ábra és táblázat is segíti a megértést. 
Az utolsó, nyolcadik fejezetben a szerzők átfogó célként fogalmazzák meg a pedagógiai rendszerek független hatás-, beválásvizsgálat rendszerének kidolgozását és bemutatását. A fejezet központi részét képezi a pedagógiai rendszerek általános hatás-, és beválásvizsgálatának folyamatleírása. Az ehhez kapcsolódó eszközök kidolgozása a szerzők szerint megteremtheti a pedagógiai rendszerek tényekkel is alátámasztható értékelésének és implementációjának lehetőségét. A fejezet szerzői kiemelten fontosnak ítélik a szerepek és felelösségi körök pontos beazonosítását. A hatáselemzés/beválásvizsgálat folyamata folyamatos visszacsatolásokat igénylö, visszajelzésekre épülő korrekciós rendszer, melynek fontos részét alkotja egyrészt az a stratégiai keret (pl. kormányprogram, üzleti terv), amelyben a pedagógiai rendszerek létrejönnek, másrészt a tudásháttér (pl. tantervelméleti, kutatás-módszertani, minőségbiztosítási), amely szintén jelentős feltétel.

A fejezet a beválásvizsgálat koncepcionális meghatározásán túl, gyakorlati, kutatásmódszertani útmutatással is szolgál megvilágítva ennek jelentőségét, valamint egy magyarországi példán keresztül mutatja be a beválásvizsgálatok néhány gyakori jellemzőjét.

A kötet szerzői igyekszenek a legfrissebb szakirodalomra támaszkodni a tanulmányok megírása során, azonban szívesen nyúlnak a klasszikus ide vonatkozó irodalmakhoz is föleg az elméleti háttér bemutatása során. Az olvasó fogalmi müvelését segíti a kötet végén található a legfontosabb fogalmakat összegző glosszárium, ahol érthetően magyarázzák meg a kötetben előforduló fogalmakat. Stílusát tekintve a kötet könnyen értelmezhetö, világos, pontos terminusokat használ. Tipográfiai szempontból hibaként róható fel, bár a kötet tartalmi értékéböl nem von le az a tény, hogy az értelmezést segítő folyamatábrák és táblázatok betümérete nem megfelelö. Esztétikai szempontból is színvonalas munkát tarthat kezében az olvasó, mely színes, mégis visszafogottan a lényeget kiemelve, de arról a figyelmet el nem vonva vezeti szemünket végig a köteten. Szerkesztési szempontból érdekesek és hasznosak a rendhagyóan a fejezetek elején található összegzések, melyek felhívják az olvasó figyelmét az adott fejezetben található főbb gondolati csomópontokra és öszszefüggésekre.

A kötetben szereplő tanulmányok szerzői és a kötet szerkesztői vállalásuknak eleget téve ebben a rendkívül informatív és gyakorlatias kézikönyvben ténylegesen megfelelő munícióval látják el az olvasóikat, egy korszerủ szemléletet is megvalósító pedagógiai rendszer tervezéséhez, készítéséhez és alkalmazásához. Ha lépésről-lépésre megfogadjuk tanácsaikat, kellö türelemmel és szakmai együttmüködéssel megszülethet saját pillangónk: egy valóban innovatív, mindenki számára elfogadott és fenntartható pedagógiai rendszer.

Falus Iván - Környei László - Németh Szilvia - Sallai Éva (szerk. 2012): A pedagógiai rendszer. Fejlesztők és felhasználók kézikönyve. Educatio Társadalmi Szolgáltató Nonprofit Kft., Budapest, 268 oldal 